\title{
IMPLEMENTASI PENDIDIKAN AKIDAH AKHLAK DALAM LINGKUNGAN SEKOLAH MTs MA'ARIF NU
}

\author{
Oleh: Hasna Firdania Febriyanti
}

\begin{abstract}
Abstrak : Penelitian ini bertujuan untuk mendeskripsikan implementasi pendidikan akidah akhlak di lingkungan sekolah. Studi ini dilakukan di MTs Ma'arif NU dengan menggunakan pendekatan kualitatif. Hasil penelitian ini menyimpulkan bahwa implementasi pendidikan akidah akhlak dilaksanakan secara baik terlihat pada pelajaran akidah akhlak yang telah diterapkan pada kegiatan kegiatan sekolah, seperti jama'ah sholat dhuha, jamaah shalat dhuhur, Do'a bersama setiap akhir kelulusan, Ziarah Wali, bakti sosial, pengajian akhir semester dan sebagainya. Salah satu guru Akidah Akhlak Mts Ma'arif NU (Drs. H. Mundzakir), menyatakan bahwa pendidikan akidah akhlak di MTs Ma'arif NU sudah diterapkan dengan baik. Adapun terdapat faktor penghambat ialah perilaku-perilaku siswa yang bertentangan dengan ajaran agama. Beberapa perilaku itu antara lain terbiasa berkata kotor, belum melaksanakan shalat lima waktu dengan tertib, kebiasaan merokok, dan bagi siswa putri masih banyak yang tidak memakai jilbab.
\end{abstract}

\section{PENDAHULUAN}

Sejalan dengan perkembangan ilmu pengetahuan dan teknologi dewasa ini kita dihadapkan pada permasalahan-permasalahan yang di antaranya adalah permasalahan dalam bidang pendidikan, politik, ekonomi, sosial, budaya. Di samping itu krisis ekonomi dan pertumbuhan penduduk yang terus meningkat menambah kompleksnya permasalahan, keadaan seperti ini sangat berpengaruh pada kehidupan individu sebagai pribadi maupun sebagai anggota masyarakat, dengan demikian individu dituntut lebih mampu menghadapi dan mengatasi berbagai masalah tersebut, maka dari itu pendidikan penting sebagai benteng untuk menghadapi tantangan tersebut.

Pendidikan adalah usaha sadar untuk menyiapkan peserta didik melalui kegiatan bimbingan pengajaran dan latihan bagi perannya di masa mendatang. Sekolah sebagai satu lembaga yang menyelanggarakan pendidikan formal memegang peranan yang sangat penting dalam mewujudkan tujuan pendidikan.

Indonesia sebagai negara yang berfalsafah Pancasila menetapkan tujuan pendidikan adalah untuk meningkatkan ketakwaan terhadap Tuhan Yang Maha Esa, kecerdasan dan keterampilan mempertinggi budi pekerti, memperkuat dan mempertebal 
semangat kepribadian dan mempertebal semangat dan cinta Tanah Air agar bisa membangun dirinya sendiri serta dalam berbangsa. ${ }^{1}$

Kedewasaan itu mencakup fungsi-fungsi individualitas, sosilitas dan moralitas, sehingga tercapai kebulatan pribadi manusia sebagai indvidu dan sebagai dari masyarakat yang untuk itu diperlukan moralitas, sehingga individu mampu mengatasi masalah yang timbul akibat perkembangan ilmu dan teknologi. ${ }^{2}$

Oleh karena itu, masalah pendidikan tidak akan pernah selesai, sebab hakikat manusia itu sendiri selalu berkembang mengikuti dinamika kehidupannya. Pendidikan adalah usaha sadar bertujuan, namun tidaklah berarti pendidikan harus berjalan secara konvensional dan tradisional.

Pendidikan merupakan suatu system yang teratur dan mengemban misi yang cukup luas yaitu segala sesuatu yang bertalian dg perkembangan fisik, kesehatan, keterampilan, pikiran, perasaan, kemauan, sosial sampai kepada masalah kepercayaan atau keimanan. Hal ini menunjukkan bahwa sekolah sebagai suatu lembaga pendidikan formal mempunyai suatu muatan beban yang cukup berat dalam melaksanakan misi pendidikan tersebut. Lebih-lebih kalau dikaitkan dengan pesatnya perubahan zaman dewasa ini yang sangat berpengaruh terhadap anak-anak didik dalam berfikir, bersikap dan berperilaku, khususnya terhadap mereka yang masih dalam tahap perkembangan dalam transisi yang mencari identitas diri. ${ }^{3}$

Adapun Pendidikan Agama Islam merupakan usaha bimbingan yang ditujukan untuk mencapai keseimbangan jasmani dan rohani menurut ajaran Islam, untuk mengarahkan dan mengubah tingkah laku, untuk mencapai pertumbuhan kepribadian yang sesuai dengan ajaran Islam dalam proses kependidikan melalui latihan-latihan kecerdasan, kejiwaan, keyakinan, kemauan dan persamaan dalam seluruh aspek kehidupan manusia.[1]

Salah satu komponen operasional pendidikan Islam adalah kurikulum, ia mengandung materi yang diajarkan secara sistematis dengan tujuan yang telah ditetapkan. Pada hakekatnya antara materi dan kurikulum mengandung arti sama, yaitu

\footnotetext{
${ }^{1}$ Muzayyin Arifin, Filsafat Pendidikan Islam, Jakarta, Pt Bumi Aksara, 2009, hlm 118

${ }^{2}$ E. Mulyasa, Implikasi kurikulum 2004 pandungan pembelajaran KPK, Bandung, PT Remaja Rosdakarya, 2005, hlm 15

${ }^{3}$ Departemen Agama, Kendali Mutu,Pendidikan Agama Islam, Jakarta, Dirjen Pembinaan Kelembagaan Agama Islam,2001, hlm 10
} 
bahan-bahan pelajaran yang disajikan dalam proses kependidikan dalam suatu system institusional pendidikan.

Materi-materi yang diuraikan dalam Al-quran menjadi bahan-bahan pokok pelajaran yang disajikan dalam proses pendidikan islam, formal maupun non formal. Oleh karena itu, materi pendidikan Islam yang bersumber dari Al-quran harus dipahami, dihayati, diyakini, dan diamalkan dalam kehidupan umat Islam.

Menurut Prof. Hasan Langgulung dasar operasional pendidikan terbagi menjadi enam macam :

1. Dasar historis, yaitu dasar yang memberikan persiapan kepada anak didik dengan hasil-hasil pengalaman masa lalu, undang-undang dan peraturannya, batas-batas dan kekurangannya.

2. Dasar sosial, yaitu dasar yang memberikan kerangka budaya pendidikannya itu bertolak dan bergerak seperti memindah budaya, memilih dan mengembangkannya.

3. Dasar ekonomi, yaitu dasra yang memberi perspektif tentang potensi-potensi manusia dan keuangan materi dan persiapan yang mengatur sumber-sumbernya dan tanggung jawabnya terhadap pembelanjaan.

4. Dasar politik dan administrasi, yaitu dasar yang memberi bingkai ideologi dasar yang digunakan sebagai tempat bertolak untuk mencapai tujuan yang dicita-citakan dan rencana yang telah dibuat.

5. Dasar psikologis, yaitu dasar yang memberi informasi tentang watak pelajar-pelajar, guru-guru cara-cara terbaik dalam praktek pencapaian dan penilaian dan pengukuran secara bimbingan.

6. Dasar filosofis, yaitu dasar yang memberi kemampua memilih yang terbaik memberi arah suatu sistem, mengontrol dan memberi arah kepada semua dasardasar operasional lainnya. ${ }^{4}$

Dengan mempelajari ilmu agama anak didik diharapkan lebih dekat kepada Allah dan dengan melalui ilmu pengetahuan yang lainnya anak didik akan mendapatkan kesejahteraan, kemajuan hidup duniawi yang menjadi bekal hidup akhiratnya. Ilmuilmu pengetahuan itu menurut pandangan Islam, tidak terlepas hubungannya dengan ilmu-ilmu Allah. Oleh karena itu, orang yang berilmu pengetahuan akan mampu

\footnotetext{
${ }^{4}$ Hasan Langgulung, Asa s-Asas Pendidikan Islam, Jakarta, PustakaAl-husna, 1988, hlm. 9-12
} 
mengenal Allah sesuai dengan prinsip-prinsip pendekatan disiplin keilmuanya masingmasing. Semuanya akan mengalir kea rah Yang Maha Esa sebagai sumber segala ilmu. ${ }^{5}$

Tantangan yang dihadapi dalam pembelajaran Akidah Akhlak adalah bagaimana mengimplementasikannya, bukan hanya mengajarkan pengetahuan tentang agama saja akan tetapi bagaimana mengarahkan peserta didik agar memiliki kualitas iman, takwa dan akhlak mulia. Dengan demikian, muatan akhlak bukan hanya mengajarkan pengetahuan tentang agama akan tetapi bagaimana membentuk kepribadian siswa agar memiliki keimanan dan ketakwaan yang kuat dan kehidupannya senantiasa dihiasi dengan akhlak yang mulia damanapun, dan dalam kondisi apapun.

Dalam realitas yang lebih sempit lagi misalnya di MTs Ma'arif NU problematika moral dan karakter juga terjadi. Berdasarkan pengamatan penulis, siswasiswa MTs Ma'arif NU yang notabenya banyak menerima pembelajaran PAI yang lebih dibandingkan sekolah umum juga masih banyak ditemui perilaku-perilaku siswa yang bertentangan dengan ajaran agama. Beberapa perilaku itu antara lain terbiasa berkata kotor, mmbelum melaksanakan shalat lima waktu dengan tertib, kebiasaan merokok, dan bagi siswa putri masih banyak yang tidak menutup aurat.

Lalu pertanyaannya apakah di MTs Ma'arif NU belum menerapkan pendidikan akhlak? Berdasarkan wawancara awal yang telah penulis lakukan dengan salah satu guru Akidah Akhlak MtsMa'arif NU, menyatakan bahwa pendidikan karakter di MTs Ma'arif NU sudah diterapkan dengan baik (Drs. H. Mundzakir, wawancara, 09 Mei 2017). Adapun di MTs Ma'arif NU adanya pembelajaran akhlak diimplementasikan melalui intensifikasi pelaksanaan pendidikan agama di sekolah. Di MTs Ma'arif NU ini memiliki berbagai kegiatan keagamaan dan beberapa kegiatan yang menunjang pembentukkan karakter akhlak seperti jama'ah sholat dhuha setiap hari selasa, rabu dan kamis, jamaah shalat dhuhur, Do'a bersama setiap akhir kelulusan,Ziarah Wali, bakti sosial, pengajian akhir semester dan sebagainya.

Berdasarkan alasan itulah, penulis tertarik untuk melakukan penelitian tentang implementasi pembelajaran Akhlak di MTs Na'arif $\mathrm{Nu}$ karena terdapat kesenjangan antaran penerapan dan hasil yang dicapai. Sekalipun pembelajaran akhlak telah diterapkan dengan melakukan proses intensifikasi pendidikan agama di sekolah namun kenyataannya perilaku-perilaku penyimpangan terhadap ajaran agama masih dilakukan

${ }^{5}$ H.M Arifin, Ilmu Pendidikan Islam, Jakarta, PT Bumi Aksara, 2003, hlm 135-140 
oleh mayoritas siswa di MTs Ma'arif NU. Dengan pertimbangan inilah maka penulis merasa perlu mengkaji lebih mendalam tentang implementasi pendidikan akhlak di MTs Ma'arif NU

Mujizatullah dalam penelitiannya yang berjudul "Implementasi Pendidikan Karakter Pada Madrasah Aliyah Puteri Aisyiah Di Palu”. Tentu ada faktor pendukung dan penghambat pelaksanaan pembelajaran tersebut. Studi ini dilakukan di Madrasah Aliyah putri Aisyiah dengan menggunakan pendekatan kualitatif. Hasil penelitian ini menyimpulkan bahwa implementasi pendidikan karakter dilaksanakan secara monolitik terlihat pada pelajaran aqidah akhlak, pengintegrasian pendidikan karakter terlihat pada proses pembelajaran pendahuluan, inti, dan penutup. Pembiasaan, pengembangan diri, karakteristik madrasah melalui pencitraan, dan komponen pendidikan, metode serta pendekatan yang digunakan dipadukan dengan metode berbasis pesantren, siswa diasramakan, sekolah dan asrama gratis. Salah satu faktor penghambat: adalah masih terdapat guru mengajar tidak sesuai dengan kompetensi profesional, pihak madrasah dan pihak asrama belum sinergi dalam menentukan kegiatan ekstrakurikuler yang berhubungan dengan pendidikan karakter. ${ }^{6}$

Pentingnya Penelitian ini untuk bisa mengetahui faktor faktor yang dapat mempengaruhi pelaksanaan belajar tersebut dan tentunya dalam mengimplementasikannya.

Perbedaan antara penelitian terdahulu dengan sekarang yaitu kalau penelitian terdahulu meneliti tentang karakter yang monolitik dan metodenya berbasis pesantren. Sedeangkan peneliti sekarang meneliti tentang pendidikan akidah akhlak yang implementasinya terhadap lingkungan sekolah dan tidak berbasis pesantren.

\section{PEMBAHASAN}

1. Pembelajaran

Ditinjau dari asal katanya, kata pembelajaran adalah terjemahan dari bahasa Inggris "instruction". Dalam cakupan maknaya, kata pembelajaran lebih luas dari mengajar, bahkan mengajar termasuk dalam aktifitas pembelajaran. Dengan pengertian ini, dapat dibedakan dengan jelas antara belajar mengajar dengan pembelajaran.

\footnotetext{
${ }^{6}$ Mujizatullah Implementasi Pendidikan Karakter Pada Madrasah Aliyah Puteri Aisyiah Di Palu , dalam www.jurnalalqalam.or.id/index.php/alqalam/article/download/181/164pdf
} 
Ada beberapa karakteristik yang melekat dalam pembelajaran, yaitu; pertama, pembelajaran berarti membelajarkan siswa. Kedua, proses pembelajaran berlangsung di mana saja. Ketiga, pembelajaran berorientasi pada pencapaian tujuan.

2. Lingkungan sekolah

Sekolah merupakan suatu lembaga pendidikan formal yang mengusahakan agar tujuan dari pembelajaran itu tercapai secara maksimal. Dan ini biasanya di selenggarakan dengan sengaja, berencana, sistematis, dan terarah. Sekolah sebagai tempat dilangsungkannya kegiatan belajar mengajar tentunya lebih terorganisir dari lembaga pendidikan non formal. Sekolah juga merupakan sarana pendidikan yang efektif dan efisien. ${ }^{7}$

a. Lingkungan fisik sekolah

Lingkungan fisik merupakan lingkungan belajar siswa yang sangat penting. Peserta didik menginginkan belajar dalam gedung dan perlengkapan fisik yang bagus serta dapat dibanggakan, dengan demikian ada kesenangan untuk bersekolah. ${ }^{8}$

b. Lingkungan sosial di sekolah

Dalam mengikuti pendidikan din sekolah si anak menyesuaikan diri dengan lingkungan, karena pada masa-masa itu mulai timbul pada perkembangan kesadaran, kewajiban belajar dan sebagainya.

Perkembanagn sosial anak iu tidak terjadi denagn begitu saja, akan tetapi melalui tahap-tahap sampai ia remaja, oleh karena itu tugas seorang guru harus bisa membina siswa-siswanya di sekolah dengan lingkungan sekolah yang baik.

Adapun lingkungan sosial di sekolah meliputi:

a. Sikap dan penampilan Guru

Faktor yang paling besar pengaruhnya dalam pendidikan yang ada di sekolah adalah seorang Guru, sehinnga guru di sini mempunyai andil yang sangat besar mengarahkan anak didik ke mana harus di bawa, oleh sebab itu penampilan seorang guru harus bisa menjadi panutan bagi anak didiknya.

Untuk lebih rincinya bahwa akhlak mulia bagi seorang guru sebagai sifat-sifat terpuji yang harus dimilikinya adalah sebagai berikut: ikhlas dan tidak

${ }^{7}$ Kurt Singer, Membina Hasrat Belajar di Sekolah, Bandung, Remaja Rosdakarya, 1987, hlm 78

${ }^{8}$ Sonjia poernomo, kesehatan sekolah di Indonesia, Jakarta, Erlangga, 1990, hlm 46 
tamak, jujur, adil dan takwa, lemah lembut, pemaaf dan musyawaroh, rendah hati, wibawa, ber ilmu luas dan bertubuh sehat, menguasai bahan pelajaran, mencintai pekerjaan, mengetahui kapasitas peserta didik, sealu ingin menambah ke ilmuannya, selalu mengajak kebaikan.

b. Sikap dan perilaku Siswa

Guru yang kurang mendekati siswa dan kurang bijak, tidak akan melihat bahwa di dalam kelas ada grup yang saling bersaing secara tiak sehat. Jiwa kelas tidak terbina, bahkan hubungan masing-masing siswa tidak tampak. Siswa mempunyai sifat atau perilaku yang kurang menyennagkan teman lain, mengalami rasa rendah diri atau sedang mengalami tekanan-tekanan batin, akan diasingkan dari kelompok. Akibatnya makin parah masalahnya dan akan mengganggu belajarnya lebih-lebih ia malas unutuk masuk sekolah dengan alasan-alasan tertentu, karena di sekolah mengalami perlakuan yang kurang menyenangkan dari teman-temannya. Jika hal itu terjadi, segerahlah siswa diberi pelayanan bimbingan dan penyuluhan agar ia kembali ke dalam kelompoknya.

Disamping itu teman bergaul juga sangat berpengaruh terhadap sikap dan perilaku siswa. Teman bergaul baik akan berpengaruh baik terhadap diri siswa, begitu juga sebaliknya, teman bergaul yang jelek pasti mempengaruhi buruk juga. $^{9}$

3. Akidah

Aqidah adalah bentuk masdar dari kata “ „aqoda, ya "qidu, "aqdan„aqidatan ” yang berarti simpulan, ikatan, sangkutan, perjanjian dan kokoh. Sedang secara teknis aqidah berarti iman, kepercayaan dan keyakinan. Dan tumbuhnya kepercayaan tentunya di dalam hati, sehingga yang dimaksud aqidah adalah kepercayaan yang menghujam atau tersimpul di dalam hati. ${ }^{10}$

Sedangkan menurut istilah aqidah adalah hal-hal yang wajib dibenarkan oleh hati dan jiwa merasa tentram kepadanya, sehingga menjadi keyakinan kukuh yang tidak tercampur oleh keraguan. ${ }^{11}$

\footnotetext{
${ }^{9}$ http//guruaqidahakhlakmenulis.blogspot.com/20011/06/pengaruh lingkungan sekolah- mata.html diakses pada tanggal 10 mei 2017

${ }^{10}$ Muhaimin Tadjab, Abd. Mujib, Dimensi-Dimensi Studi Islam , Surabaya: Karya Abditama, 1994, hlm 241-242.

${ }^{11}$ Abdullah bin „Abdil Hamid al-Atsari, Panduan Aqidah Lengkap, Bogor, Pustaka Ibnu Katsir, 2005, hlm 28 .
} 
4. Akhlak

Sedang pengertian akhlak secara etimologi berasal dari kata "Khuluq" dan jama "nya "Akhlaq", yang berarti budi pekerti, etika, moral. Demikian pula kata "Khuluq” mempunyai kesesuaian dengan "Khilqun", hanya saja khuluq merupakan perangai manusia dari dalam diri (ruhaniah) sedang khilqun merupakan perangai manusia dari luar (jasmani). ${ }^{12}$

Ibnu Maskawaih dalam bukunya "Tahdzibul Akhlak Wa That-hirul A"raq" mendefinisikan akhlak dengan keadaan gerak jika yang mendorong ke arah melakukan perbuatan dengan tidak memerlukan pikiran. ${ }^{13}$

Dengan demikian pembelajaran aqidah akhlak adalah upaya sadar dan terencana dalam menyiapkan peserta didik untuk mengenal, memahami, menghayati dan mengimani Allah SWT dan merealisasikannya dalam perilaku akhlak mulia dalam kehidupan sehari-hari berdasarkan Qur"an dan Hadits melalui kegiatan bimbingan, pengajaran, latihan, serta penggunaan pengalaman Dibarengi tuntutan untuk menghormati penganut agama lain danhubungannya dengan kerukunan antar umat beragama dalam masyarakat hingga terwujud kesatuan dan persatuan bangsa. ${ }^{14}$

Menurut departemen Agama, pendidikan akidah akhlak di Madrasah Tsanawyah cukupan pembahaannya antara lain sebagai berikut:

a. Aspek akidah terdiri atas keimanan kepada sifat wajib, mustahil dan jaiz allah, keimanan kepada kitab Allah, Rasul Allah, sifat-sifat dan mu'jizatnya dari hari kiamat.

b. Aspek akhlak terpuji yang terdiri atas khauf, raja, taubat, tawadhu, ikhlas, bertauhid inovatif, kreatif, percaya diri, tekad yang kuat, ta'aruf, ta'awun, tafahum, jujur, adil, amanah, menepati janji, dan bermusyawarah.

c. Aspek akhlak tercela meliputi kompetesi dasar kufur, syirik, munafik, namimah, dan ghadab. ${ }^{15}$

5. Tujuan mata pelajaran akidah akhlak

Bidang studi akidah akhlak ini bertujuan untuk menumbuhkan dan meningkatkan keimanan peserta didik yang diwujudkan dalam akhlaknya yang

\footnotetext{
12 Ibid., 243.

${ }^{13}$ Ibid., 243.

${ }^{14}$ DEPAG, Kurikulum dan Hasil Belajar Aqidah Akhlak...,hlm 2.

${ }^{15}$ Depag,Kurikulum dan hasil belajar Akidah Akhlak Madrasah Tsanawiyah, Jakarta, 2003, hlm 45
} 
terpuji, melalui pemberian dan penumpukkan pengetauan, penghayatan, pengalaman peserta didik tentang akidah dan akhlak islam. Sehingga manusia muslim yang terus berkembang dan meningkatkan kualitas keimanan dan ketakwaan kepada allah SWT, serta berakhlak mulia dalam kehidupan pribadi, masyarakat, berbangsa dan bernegara serta untuk dapat melanjutkan pada jenjang pendidikan yang lebih tinggi. ${ }^{16}$

6. Konsep Pembentukan Karakter Siswa

Jika dilihat dari usul kata "karakter" ini berasal dari kata dalam bahasa latin, yaitu kharakter, kharassein, dan kharax, yang bermakna tools for marking, to enggrave, dan pointed stake. Kata ini konon mulai banyak digunakan dalam bahasa Perancis sebagai caractere pada abad ke-14. Ketika masuk ke dalam bahasa Inggris, kata caractere ini berubah menjadi character. Adapun di dalam bahasa Indonesia kata character ini mengalami perubahan menjadi "karakter". ${ }^{17}$

Menurut bahasa, karakter adalah tabiat atau kebiasaan. Sedangkan menurut ahli psikologi, karakter adalah sebuah sistem keyakinan dan kebiasaan yang mengarahkan tindakan seorang individu. Karena itu, jika pengetahuan mengenai karakter seseorang itu dapat diketahui, maka dapat diketahui pula bagaimana individu tersebut akan bersikap untuk kondisi-kondisi tertentu. ${ }^{18}$

Pendidikan karakter (character education) dalam konteks sekarang sangat relevan untuk mengatasi krisis moral yang sedang melanda di negara kita. Krisis tersebut antara lain berupa meningkatnya pergaulan bebas, maraknya angka kekerasan anak-anak dan remaja, kejahatan terhadap teman, pencurian remaja, kebiasaan menyontek, pornografi, dan perusakan milik orang lain sudah menjadimasalah sosial yang hingga saat ini belum dapat diatasi secara tuntas, oleh karena itu betapa pentingnya pendidikan karakter. ${ }^{19}$

\section{METODE}

\footnotetext{
${ }^{16}$ http:/guruaqidahakhlakmenulis.blogspot.com/20011/06/tujuan-dan-kegunaan-mempelajari-mata.html diakses pada tanggal 10 mei 2017

${ }^{17}$ Sugiono Wibowo, Manajemen Pendidikan Karakter di Sekolah, Pustaka Pelajar, Jogjakarta, 2013, hlm 7.

${ }^{18}$ N.K. Singh dan Mr. A.R. Agwan, Encyclopaedia of the Holy Qur"ân, New Delhi: balaji Offset, 2000, Edisi I, hlm 175 .

${ }^{19}$ Nana Syaodih Sukmadinata, Metode Penelitian Pendidikan Bandung: PT Rosda Karya, 2007,hlm 60.
} 
Metode yang digunakan ini adalah Metode Penelitian lapangan dan bersifat deskriptif kualitatif yang bertujuan untuk mengetahui Implementasi sistem pembelajaran pendidikan akhlak dalam pembelajaran Akidah Akhlak di MTs Ma'arif NU. Pendekatan yang digunakan dalam penelitian ini adalah pendekatan studi kasus. Subyek penelitian ini adalah guru Akidah Akhlak, peserta didik, waka kurikulum, kepala sekolah/madrasah. Teknik pengumpulan data yang digunakan peneliti adalah obervasi, interview, dan dokumentasi.

Triangulasi yang akan digunakan penulis adalah triangulasi sumber yaitu membandingkan dan mengecek balik derajat kepercayaan suatu informasi yang diperoleh melalui waktu dan alat yang berbeda dalam penelitian kualitatif. Hal ini dapat dicapai dengan jalan: 1) membandingkan data hasil pengamatan dengan data hasil wawancara, 2) membandingkan apa yang dikatakan orang di depan umum dengan apa yang dikatakannya secara pribadi, 3) membandingkan apa yang dikatakan orang-orang tentang situasi penelitian dengan apa yang dikatakan sepanjang waktu, 4) membandingkan keadaan dan perspektif seseorang dengan berbagai pendapat dan pandangan orang seperti rakyat biasa, orang yang berpendidikan menengah atau tinggi, orang berada, orang pemerintahan, dan 5) membandingkan hasil wawancara dengan isi suatu dokumen yang berkaitan. Teknik ini digunakan untuk memeriksa keabsahan data hasil wawancara dengan informan atau subyek penelian.

\section{Hasil Penelitian}

Lingkungan adalah segala sesuatu yang ada disekitar anak didik baik berupa benda-benda, peristiwa-peristiwa yang terjadi maupun kondisi masyarakat terutama yang dapat memberikan pengaruh kuat kepada anak yaitu lingkungan dimana proses pendidikan berlangsung dan lingkungan dimana anak-anak bergaul sehari-harinya.

Beberapa ahli membagi lingkungan menjadi tiga bagian yaitu lingkungan keluarga, sekolah dan masyarakat. Ketiga lingkungan ini merupakan satu kesatuan yang tak boleh dipisahkan, hal ini karena ketiganya berpengaruh terhadap perkembangan anak didik menuju ke arah kedewasaan jasmani dan rohani.

Pengaruh lingkungan terhadap anak didik dapat positip dapat pula negatif. Positif apabila dapat memberikan dorongan terhadap keberhasilan proses pendidikan, 
sedangkan pengaruh negatif apabila lingkungan menghambat keberhasilan proses pembentukan karakter Siswa.

Secara bahasa karakter berasal dari bahasa Yunani yaitu charassein yang artinya mengukir. ${ }^{20}$ Sifat utama ukiran adalah melekat kuat di atas benda yang diukir. Tidak mudah usang tertelan waktu atau aus terkena gesekan. Menghilangkan ukuran sama saja dengan menghilangkan benda yang diukir itu. Sebab, ukiran melekat dan menyatu dengan bendanya. Ini berbeda dengan gambar atau tulisan tinta yang hanya disapukan di atas permukaan benda. Karena itulah, sifatnya juga berbeda dengan ukiran, terutama dalam hal ketahanan dan kekuatannya dalam menghadapi tantangan waktu.

Jadi yang dimaksud dengan karakter akhlak adalah suatu sistem penanaman nilai-nilai karakter kepada warga sekolah yang meliputi komponen pengetahuan, kesadaran atau kemauan dan tindakan untuk melaksanakan nilai-nilai tersebut, baik terhadap Allah SWT, diri sendiri, sesama, lingkungan, maupun kebangsaan sehinggan menjadi manusia insan kamil. ${ }^{21}$

Pada hasil penelitian akhir ini ialah dapat kita ketahui bahwa terdapat kesenjangan antaran penerapan dan hasil yang dicapai siswa. Sekalipun pembelajaran akhlak telah diterapkan dengan melakukan proses intensifikasi pendidikan agama di sekolah namun kenyataannya perilaku-perilaku penyimpangan terhadap ajaran agama masih dilakukan oleh mayoritas siswa di MTs Ma'arif NU. Dan tidak dapat dipungkiri bahwa pengaruh faktor dari luar lingkungan sekolah yang juga dapat mempropokatori dari perbuatan buruk, misal merokok, belum bisa berbahasa dengan baik dan sopan ketika sedang berbicara dengan Guru ,dan bagi siswa perempuan yang masih banyak tidak menggunakan jilbab, akan tetapi implementasi pembelajaran akhlak diimplementasikan melalui intensifikasi pelaksanaan pendidikan agama di sekolah. Di MTs Ma'arif NU ini memiliki berbagai kegiatan keagamaan dan beberapa kegiatan yang menunjang pembentukkan karakter akhlak seperti jama'ah sholat dhuha setiap hari selasa, rabu dan kamis, jamaah shalat dhuhur, Do'a bersama setiap akhir kelulusan,Ziarah Wali, bakti sosial, pengajian akhir semester dan sebagainya.

\footnotetext{
${ }^{20}$ Muhaimin, Pengembangan Kurikulum Agama Islam ,Jakarta, PT Raja Grafindo Persada,2007, hlm. 1014.

${ }^{21}$ Workshop, Pendidikan Karakter, Surabaya: Gedung YP. Al Islah, 2010, hlm. 3
} 


\section{SIMPULAN}

Keseluruhan definisi akhlak tersebut di atas tampak tidak terdapat pertentangan yang signifikan, melainkan memiliki kemiripan satu sama lain. Definisi-definisi akhlak tersebut secara substansi tampak saling melengkapi satu sama lain, dan pembahasan definisi di atas dapat di tarik konklusi mengenai empat (4) ciri yang terdapat dalam akhlak, yaitu: pertama, akhlak adalah perbuatan yang telah tertanam kuat dalam jiwa seseorang, sehingga telah menjadi kepribadiannya. Kedua, akhlah adalah perbuatan yang dilakukan dengan mudah dan tanpa pemikiran (spontanitas). Ketiga, akhlak adalah perbuatan yang timbul dri dalam diri orang yang mengerjakannya tanpa ada intervensi dari luar. Keempat, akhlak adalah perbuatan yang dilakukan dengan sesungguhnya, bukan main-main atau karena rekayasa.

Dari penjelasan di atas dapat di ambil kesimpulan tentang definisi pendidikan akhlak. Pendidikan akhlak adalah "pendidikan mengenai dasar-dasar moral, etika dan keutamaan budi pekerti, tabi'at yang harus dimiliki dan dijadikan kebiasaan-kebiasaan yang baik sehingga menghasilkan perubahan terhadap perkembangan jasmani dan rohani yang dimanifestasikan dalam bentuk kenyataan hidup menuju terbentuknya kepribadian yang utama yang sesuai dengan nilai-nilai ajaran Islam".

\section{REFERENSI}

[1] M. Suradji, "Upaya Guru Agama Islam dalam Membina Akhlaq Siswa," DAR EL-ILMI

J. Stud. Keagamaan, Pendidik. dan Hum., vol. 4, no. 1, pp. 18-38, 2017.

Muzayyin, Arifin. 2009. Filsafat Pendidikan Islam, Jakarta, Pt Bumi Aksara.

Mulyasa. 2005. Implikasi kurikulum 2004 pandungan pembelajaran KPK, Bandung PT Remaja Rosdakarya

Departemen Agama, Kendali Mutu. 2001. Pendidikan Agama Islam, Jakarta, Dirjen Pembiaan Kelembagaan Agama Islam

Arifin. 2003. Ilmu Pendidikan Islam, Jakarta, PT Bumi Aksara

Muhaimin. 2007. Pengembangan Kurikulum Agama Islam, Jakarta, PT Raja Grafindo Persada

Workshop. 2010. Pendidikan Karakter, Surabaya, Gedung YP. Al Islah

Singer, Kurt. 1987. Membina Hasrat Belajar di Sekolah, Bandung, Remaja Rosdakarya Poernomo, Sonjia. 1990. kesehatan sekolah di Indonesia, Jakarta, Erlangga 
http//guruaqidahakhlakmenulis.blogspot.com/20011/06/pengaruh lingkungan sekolahmata.html diakses pada tanggal 10 mei 2017

Muhaimin, Tadjab. Abd, Mujib. 1994. Dimensi-Dimensi Studi Islam, Surabaya, Karya Abditama

Abdullah, bin Abdil Hamid al-Atsari. 2005. Panduan Aqidah Lengkap, Bogor, Pustaka Ibnu Katsir

Depag. 2003. Kurikulum dan hasil belajar Akidah Akhlak Madrasah Tsanawiyah, Jakarta

http:/guruaqidahakhlakmenulis.blogspot.com/20011/06/tujuan-dan-kegunaanmempelajari-mata.html diakses pada tanggal 10 mei 2017

Wibowo, Sugiono. 2013. Manajemen Pendidikan Karakter di Sekolah, Jogjakarta, Pustaka Pelajar

Singh. Agwan. 2000. Encyclopaedia of the Holy Qur'an, New Delhi, balaji Offset Sukmadinata, Nana Syaodih. 2007. Metode Penelitian Pendidikan, Bandung, PT Rosda Karya

Mujizatullah. Implementasi Pendidikan Karakter Pada Madrasah Aliyah Puteri aisyah di Palu , dalam www.jurnalalqalam.or.id/index.php/alqalam/article/download/181/164 pdf Hasan, Langgulung. 1988. Asas-Asas Pendidikan Islam, Jakarta, Pustaka Al-husna 